\title{
Leukocyte Adhesion Deficiency Type 3
}

National Cancer Institute

\section{Source}

National Cancer Institute. Leukocyte Adhesion Deficiency Type 3. NCI Thesaurus. Code C154615.

An autosomal recessive condition caused by mutation(s) in the FERMT3 gene, encoding fermitin family homolog 3. It is characterized by a defect in activation of all beta integrins. It manifests clinically as severe infections with marked leukocytosis, accompanied by lifethreatening bleeding episodes. 